\title{
Effects of Nitroglycerine on Renal Ischemia-Reperfusion Injury in Adult Male Rats
}

\author{
Authors \\ Fatemeh Ahmadi ${ }^{1}$, Saeed Hajihashemi ${ }^{2}$, Ali Rahbari ${ }^{3}$, Fatemeh Ghanbari ${ }^{4}$
}

\author{
Affiliations \\ 1 Arak University of Medical Sciences, Arak, Iran \\ 2 Department of Physiology, Faculty of Medicine, Arak \\ University of Medical Sciences, Arak, Iran \\ 3 Department of Pathology, Arak University of Medical \\ Sciences, Arak, Iran \\ 4 Department of Pharmacology, Islamic Azad University, \\ Arak Branch, Arak, Iran
}

Key words

nitroglycerine, renal ischemia-reperfusion injury, rat

$\begin{array}{lr}\text { received } & 13.04 .2019 \\ \text { accepted } & 11.06 .2019\end{array}$

Bibliography
DOI https://doi.org/10.1055/a-0958-1987
Published online: 17.7.2019
Drug Res 2019; 69: 612-620
C Georg Thieme Verlag KG Stuttgart · New York
ISSN 2194-9379

\section{Correspondence}

Saeed Hajihashemi

Department of Physiology

Faculty of Medicine

Arak University of Medical Sciences

Baseej Square

Sardasht
Arak

38481-7-6941 Markazi

Iran

Tel.:+98/86/34173 502 (extension 354), Fax:+98/863/4173 529

hajihashemi@arakmu.ac.ir; s.hajihashemi@gmail.com

\section{ABSTRACT}

Background Ischemia-reperfusion (I-R) leads to acute kidney injury (AKI). The present study investigated the effects of nitroglycerine (NG) on improving renal dysfunctions caused by $\mathrm{I}-\mathrm{R}$ in rats.

Methodology Twenty-four rats were equally divided into four groups: (1) the control group, (2) the sham group, (3) the I-R group, and (4) NG-treated groups.NG $(50 \mu \mathrm{g} / \mathrm{kg})$ was injected intraperitoneally after induction of IR. I-R was induced through clamping of the bilateral renal artery and vein of both kidneys for $20 \mathrm{~min}$ followed by $24 \mathrm{~h}$ of reperfusion.

Results NG significantly increased the creatinine clearance levels and renal blood flow rate (which was reduced by I-R). NG also significantly improved serum electrolytes (sodium and potassium) that were disordered by I-R. In addition, NG significantly offset impaired antioxidant defense mechanism and inhibited lipid peroxidation.

Conclusions The results show NG has a protective effect on renal tissue against AKI caused by I-R. These protective effects mediated through antioxidant activity and decrease of lipid peroxidation.

\section{Introduction}

AKI has been defined as a sudden reduction (for a few hours) in kidney function with structural damage and loss of function [1]. AKI is manifested by a significant increase in serum $\mathrm{Cr}$ and reduction of urine output [2]. The pathophysiology of AKI is divided into tubular and vascular causes. In the AKI induced by vascular damage, renal medullary blood flow decreases, leading to a reduction in total renal perfusion. The AKI is associated with damage to the endothelium of arterioles, characterized by the increased vascular contraction in response to elevated tissue levels of endothelin I and II, thromboxane A2, and leukotrienes C4 and D4. Moreover, vasodilation decreases in response to acetylcholine, bradykinin, and nitric oxide [3]. The renal injury initiates from the onset of ischemia and continues after the reperfusion, the tissues undergo subsequent damage. Generation of cytokine and oxygen free radicals also neutrophil accumulation occurs in renal ischemia and reperfusion injury. During Ischemia the tubular cells and their residues are separated from the basement membrane that reacts with proteins like fibronectin and forms protein casts that causes a tubular obstruction and, therefore, increased intratubular pressure [4]. In renal ischemia and reperfusion injury, the tubular disruption activates the tubuloglomerular feedback mechanism that reduces glomerular filtration rate (GFR) to prevent water and electrolytes loss [5]. The animal ischemia-reperfusion model is used in fundamental and treatment studies on AKI [6]. 
Nitric oxide (NO) is an effector molecule and a lipophilic free radical, the physiological effects of which are exerted by cGMP [7]. NO has a half-life of 6-30 s [8] and in the kidney is produced by three isoforms of NOS: endothelial NOS(eNOS or NOS3) in renal vessels, neuronal NOS (nNOS or NOS1) in the macula densa, and inducible NOS (iNOS or NOS2) in renal tubular segments, in the glomerulus, and intertubular and renal arcuate arteries [9].

The molecular and chemical effects of NO are administered by preventing neutrophil filtration, reducing the pro-inflammatory cytokines, inhibiting platelet aggregation and therefore reducing vascular inflammation and improving perfusion to ischemic tissue [10-12]. The role of NO in the regulation of endothelium vasomotor tone decreases the effect of vascular contraction and promotes endothelial-dependent vasodilatation, which improves perfusion to ischemic tissue $[8,10]$.

Nitroglycerin (NG) is a potent vasodilator has been used in the treatment of angina pectoris heart failure and high blood pressure acts through the liberation of nitric oxide (NO) . NG is an organic nitrate that reacts with thiols and other reducing substrates [11]. It is converted into 1, 2- glyceryl dinitrate and nitrite in the vascular smooth muscle cells, which is then metabolized by mitochondrial aldehyde dehydrogenase 2 with a half-life of $1-4$ min $[13,14]$.

Regarding the NO characteristics and the ability of nitroglycerin to release exogenous nitric oxide (NO donor) in our present study, we aim to evaluate the effects of treatment with nitroglycerin after renal ischemic reperfusion injury.

\section{Materials and Methods}

This study was conducted on 24 Wistar rats weighing 250-300 g and kept in separate cages under a photoperiod of $12 \mathrm{~h}$ light $/ 12 \mathrm{~h}$ dark at room temperature (about $23 \pm 2{ }^{\circ} \mathrm{C}$ ) and with ad libitum access to food and water. All ethical codes created by the Monitoring Committee for Laboratory Animals of Arak University of Medical Sciences were complied with for all of the studied rats. The study groups included: (1) the control group that did not receive any drugs, (2) the sham group that were anesthetized without any ischemia (the kidneys were only touched), (3) the I-R group that experienced bilateral ischemia of the renal arteries and veins for $20 \mathrm{~min}$ and then reperfusion for $24 \mathrm{~h}$, and (4) the post-treatment group that were injected with intra peritoneal (IP) NG (Caspian Tamin, Iran) at $50 \mu \mathrm{g} / \mathrm{kg}, 24 \mathrm{~h}$ after reperfusion started [15].

To induce $\mathrm{AKI}$, the rats were weighed first and then injected with IP sodium thiopental (Sandoz, GmbH, Estonia) at $25 \mu \mathrm{g} / \mathrm{kg}$ [16]. After shaving the hair on the back of the rats, $1.5 \mathrm{~cm}$ incisions were made on either side of the midline using scissors and forceps. When the kidneys became visible, a special clamp was employed to block renal arteries and veins for $20 \mathrm{~min}$., after which the clamps were removed immediately. The surgery sites were then closed and the animal's recovered.

After recovery, the rats were placed in metabolic cages and the 12-h urine volume was measured using the gravimetric method. The rats were anesthetized $24 \mathrm{~h}$ after reperfusion. Systolic blood pressure was measured using a Power Lab instrument (AD Instruments, Australia) $[17,18]$ and employing the tail-cuff method. A longitudinal incision was then made on the surface of the abdo- men using a razor blade. When the abdomen was opened, the kidneys were revealed. The artery and vein of the left kidney were separated and renal blood flow (RBF) was measured for 30 min using a flow meter equipped with a special probe (T402, America) and blood flow was recorded as a chart $[19,20]$.

A cold blood collection heparin syringe was used to collect blood from the abdominal aorta. After obtaining the plasma, an Auto Analyzer (Selectra-XL, Netherlands) was employed to measure plasma $[\mathrm{Cr}]$ and [blood urea nitrogen (BUN)] in the serum and blood samples [21]. A flame photometer (SEAC-20Fp, Italy) was used to measure $\left[\mathrm{Na}^{+}\right]$and $\left[\mathrm{K}^{+}\right]$and an osmometer (Gonotec Osmomat-030, Germany) to measure osmolality [22, 23]. Creatinine clearance level and absolute and relative excretions of potassium and sodium were determined using the following equation [24]:

$$
\operatorname{CCr}(\mu \mathrm{l} / \mathrm{min} / \mathrm{gkw})=\left(\mathrm{V}^{\circ} / 1000 \times \mathrm{UCr}\right) / \mathrm{PCr}
$$

Absolute sodium excretion $\mathrm{UNaV}^{\circ}(\mu \mathrm{mol} / \mathrm{min} / \mathrm{gkw})=$ $\left(\mathrm{V}^{\circ} \times \mathrm{UNa}\right) / 1000$

Absolute excretion of potassium UKV ${ }^{\circ}(\mu \mathrm{mol} / \mathrm{min} / \mathrm{gkw})=$ $\left(V^{\circ} \times U K\right) / 1000$

Relative sodium excretion based on percentile $\mathrm{FENa}=$ $(\mathrm{UNa} \times \mathrm{PCr}) /(\mathrm{PNa} \times \mathrm{UCr}) \times 100$

Relative potassium excretion base on percentile FEK = $(\mathrm{Uk} \times \mathrm{PCr}) /(\mathrm{Pk} \times \mathrm{UCr}) \times 100$

Both kidneys were removed and weighing them, they were divided into two halves. The right kidney was placed in liquid nitrogen for the ferric reducing antioxidant power (FRAP) and malondialdehyde (MDA) biochemical analyses and then immediately placed in a freezer at $-20^{\circ} \mathrm{C}$. The amount of lipid peroxidation was determined by Okawa's MDA method. Benzie and Strain's method was used to measure FRAP $[25,26]$.

The capsule of the left kidney was separated and placed in $10 \%$ buffered formalin. It was then fixed, dehydrated, and clarified before being embedded in melted paraffin. Following that, 5-micronthick sections were prepared and stained with hematoxylin and eosin. Examination of tissue from prepared slides was performed by an expert pathologist.

Bowman's capsule space, reduction in the number of glomerular red blood cells (RBC), shedding of tubular epithelial cells into the lumen, formation of protein casts inside the lumen, and vacuolation and necrosis of tubular cells were evaluated. The amount of inflicted damage was graded based on calculated percentages as follows: no damage: grade $0,1-25 \%$ damage: grade 1, 25-50\% damage: grade 2, 50-75\% damage: grade 3 and $75-100 \%$ damage: grade 4 [27].

In addition, all data were analyzed with SPSS version 25 (Chicago, II., USA), one-way variance (ANOVA), the Tukey test, Kruskal-Wallis multiple comparison test, and Dunnett's test at $\mathrm{P}<0.05$ as the significance level for statistical analysis [28]. 


\section{Result}

\section{The effects of post-treatment NG on RBF and systolic blood pressure}

In compared to the control group, RBF showed a significant decrease in the NG group $(7.36 \pm 0.02 \mathrm{ml} / \mathrm{min} ., \mathrm{P}<0.001)$, in the $\mathrm{I}-\mathrm{R}$ group $(6.42 \pm 0.31 \mathrm{ml} / \mathrm{min} ., P<0.001)$, and in the sham group $(8.5 \pm 0.2 \mathrm{ml} / \mathrm{min} ., \mathrm{P}<0.01)$. The $\mathrm{NG}$ group showed a significant increase compared to the I-R group $(P<0.01)$. There were no significant differences between the groups in systolic blood pressure ( Fig. 1).

\section{Post-treatment effects of NG on Creatinine clearance $\left(\mathrm{C}_{\mathrm{Cr}}\right)$, absolute $\left(\mathrm{U}_{\mathrm{Na}} \mathrm{V}^{\circ}\right)$ and relative (FENa) excretions of sodium, and absolute $\left(\mathrm{U}_{\mathrm{k}} \mathrm{V}^{\circ}\right)$ and relative $\left(\mathrm{FE}_{\mathrm{k}}\right)$ excretions of potassium}

Results indicated that creatinine clearance declined significantly in the I-R group $(0.008 \pm 0.005 \mu \mathrm{l} / \mathrm{min}$. gkw; $\mathrm{P}<0.001)$ and in the NG group $(0.02 \pm 0.006 \mu \mathrm{l} / \mathrm{min} . \mathrm{gkw})$ compared to the control and sham

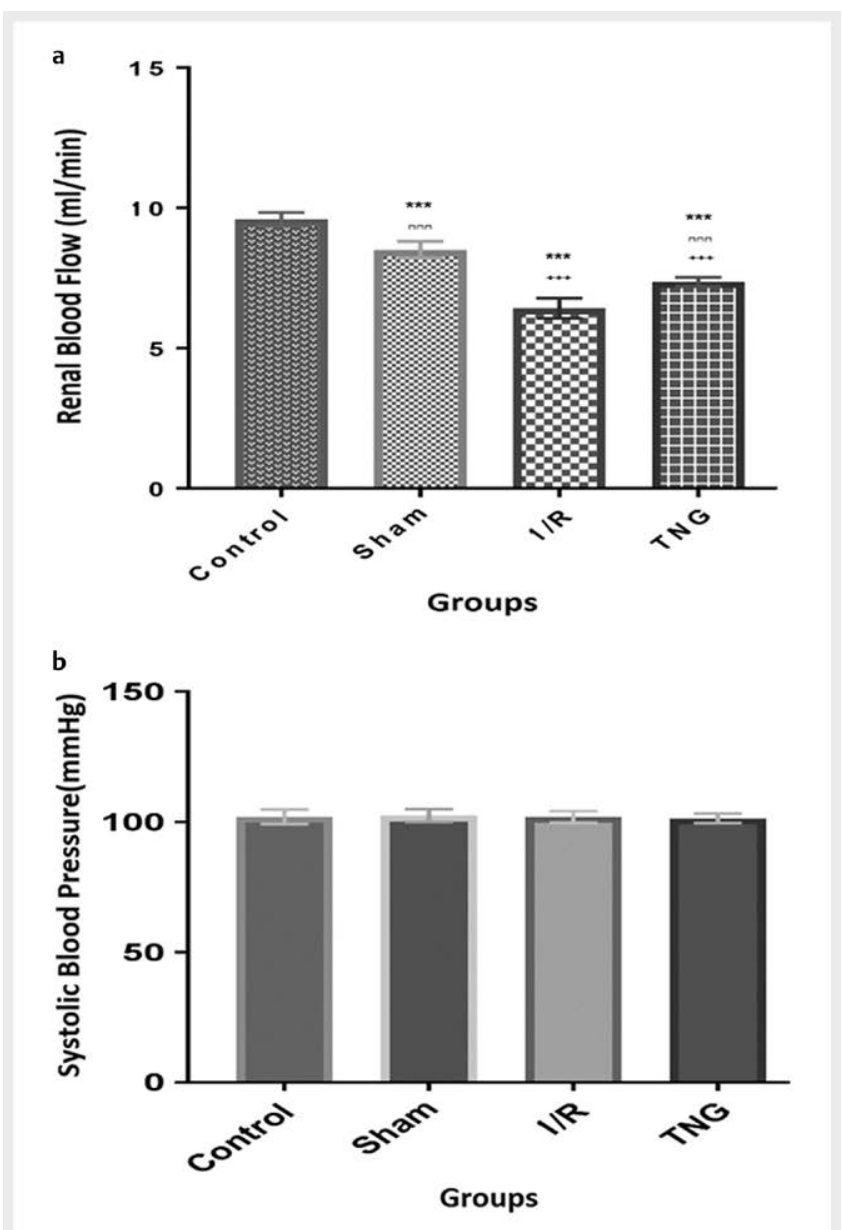

- Fig. 1 Comparison of a Renal blood flow and $\mathbf{b}$ Systolic blood pressure among the groups. $\mathrm{P}<0.001 * * *$ compared to the control group, $\mathrm{P}<0.001+++$ compared to the sham group, $\mathrm{P}<0.001 \square \mathrm{Cu}$ compared to the I-R group, Results expressed in mean \pm standard deviation (SD) for 6 rats in each group. groups $(0.05 \pm 0.01 \mu \mathrm{l} / \mathrm{min} . \mathrm{gkw})$. There was a significant increase of $C_{C r}$ in the $N G$ group $(P<0.001)$.

There was a non-significant increase in the fractional excretion of $\mathrm{Na}^{+}\left(\mathrm{FE}_{\mathrm{Na}}\right)$ of the $\mathrm{I}-\mathrm{R}$ group compared to the control group $(0.42 \pm 0.2 \%$ vs. $0.39 \pm 0.3 \%)$. The $\mathrm{FE}_{\mathrm{Na}}$ in the $\mathrm{NG}$ group $(0.001 \pm 0.0008 \%)$ declined significantly compared to the $I-R$ group at $P<0.01$ and the control group at $P<0.05$, but was not significantly different from that of the sham group. The absolute excretion of $\mathrm{Na}^{+}\left(\mathrm{U}_{\mathrm{Na}} \mathrm{V}^{\circ}\right)$ did not differ significantly among the groups. The fractional excretion of potassium $\left(\mathrm{FE}_{\mathrm{K}}\right)$ in the I-R group showed a significant increase compared to the control group (47.28 $\pm 13.3 \%$ vs. $28.6 \pm 9.8 \%, P<0.05)$. Moreover, the $\mathrm{FE}_{\mathrm{K}}$ decreased significantly in the NG group $(21.73 \pm 7.7 \%)$ compared to the sham group $(47.74 \pm 13.8 \%, P<0.05)$ and the $I-R$ group (47.28 $\pm 13.3 \%$ ), but had no significant difference with that of the control group. The absolute excretion of $\mathrm{K}^{+}\left(\mathrm{U}_{\mathrm{k}} \mathrm{V}^{\circ}\right)$ in the I-R group $(0.82 \pm 0.2 \mu \mathrm{mol} / \mathrm{min} . \mathrm{gkw}, \mathrm{P}<0.001)$ declined significantly compared to the control and sham groups $(2.68 \pm 0.3$ and $2.16 \pm 0.2 \mu \mathrm{mol} / \mathrm{min}$. $\mathrm{gkw}$, respectively), whereas there were no significant differences between the NG and the I-R groups ( $\triangleright$ Table 1)

\section{Post-treatment effects of NG on urinary levels of sodium $\left([\mathrm{Na}]_{\mathrm{u}}\right)$, potassium $\left([\mathrm{K}]_{\mathrm{u}}\right)$, creatinine $\left([\mathrm{Cr}]_{\mathrm{u}}\right)$, and osmolality (Osmol $\mathrm{u})$}

Urinary sodium concentration in the I-R group was significantly higher than the control group $(28.72 \pm 8.4 \mu \mathrm{mol} / \mathrm{mL}$ vs. $65.73 \pm 6.9 \mu \mathrm{mol} /$ $\mathrm{mL}, \mathrm{P}<0.001)$. The urinary concentration of sodium in the $\mathrm{NG}$ group $(32.11 \pm 5.3 \mu \mathrm{mol} / \mathrm{mL})$ did not differ significantly from those in the sham $(32.33 \pm 3.9 \mu \mathrm{mol} / \mathrm{mL})$ and control groups. The urinary concentration of sodium in the NG group declined significantly compared to the I-R group $(\mathrm{P}<0.001)$.

Urinary potassium concentration in the I-R group exhibited a significant decrease compared to the control group $(133.63 \pm 13.6 \mu \mathrm{mol} /$ $\mathrm{mL}$ vs. $112.9 \pm 2.7 \mu \mathrm{mol} / \mathrm{mL}, \mathrm{P}<0.01)$. The urinary concentration of potassium in the NG group $(88.76 \pm 5.8 \mu \mathrm{mol} / \mathrm{mL})$ was significantly lower than those in the sham $(120.28 \pm 9.13 \mu \mathrm{mol} / \mathrm{mL}, \mathrm{P}<0.001)$ and control groups $(P<0.001)$ and in the $I-R$ group $(P<0.01)$. Although urinary potassium concentration in the I-R group was lower than that in the sham group, this difference was not significant. The groups did not exhibit any significant differences in urinary concentration of creatinine.

Urine osmolality in the I-R group decreased significantly compared to the control group $\left(908.33 \pm 48.12 \mathrm{mOsm} / \mathrm{KgH}_{2} \mathrm{O}\right.$ vs. $\left.1515 \pm 70.5 \mathrm{mOsm} / \mathrm{KgH}_{2} \mathrm{O}, \mathrm{P}<0.001\right)$. Urine osmolality in the $\mathrm{NG}$ group $\left(1031.5 \pm 58.23 \mathrm{mOsm} / \mathrm{KgH}_{2} \mathrm{O}, \mathrm{P}<0.001\right)$ declined significantly compared to the sham $\left(1493.83 \pm 80.85 \mathrm{mOsm} / \mathrm{KgH}_{2} \mathrm{O}\right)$ and control groups $(\mathrm{P}<0.001)$, but did not differ significantly compared to the I-R group ( $\triangleright$ Table 2 ).

\section{Post-treatment effects of NG on plasma concentrations of sodium $\left([\mathrm{Na}]_{\mathrm{p}}\right)$, potassium $\left([\mathrm{K}]_{\mathrm{p}}\right)$, creatinine $\left([\mathrm{Cr}]_{\mathrm{p}}\right)$, urea $\left([\mathrm{BUN}]_{\mathrm{p}}\right)$, and osmolality (Osmol $)^{\text {) }}$}

Results indicated that plasma creatinine concentration in the I-R group $(1.24 \pm 0.35 \mathrm{mg} / \mathrm{dL})$ significantly increased $(P<0.001)$ compared to the control group $(0.55 \pm 0.09 \mathrm{mg} / \mathrm{dL})$ and the sham group $(0.64 \pm 0.08 \mathrm{mg} / \mathrm{dL})$, whereas in the NG group plasma creatinine concentration $(0.77 \pm 0.13 \mathrm{mg} / \mathrm{dL}, \mathrm{P}<0.01)$ exhibited a significant 
reduction compared to the I-R group, but did not significantly differ from those of the control and sham groups.

Plasma concentration of BUN in the I-R group $(41.11 \pm 6.5 \mathrm{mg} / \mathrm{dL})$ significantly increased compared to the control group $(18.76 \pm 2.4 \mathrm{mg} /$ $\mathrm{dL}, \mathrm{P}<0.001)$ and the sham group $(24.9 \pm 3.1 \mathrm{mg} / \mathrm{dL}, \mathrm{P}<0.01)$. There were no significant differences between the NG and the I-R groups.
Compared to the control group, plasma concentration of sodium in the I-R group experienced a decline, which was not significant $(149.23 \pm 6.2 \mu \mathrm{mol} / \mathrm{ml}$ vs. $152.1 \pm 6.1 \mu \mathrm{mol} / \mathrm{mL}, \mathrm{P}<0.01)$. The plasma concentration of sodium in the $\mathrm{NG}$ group $(141.46 \pm 2.6 \mu \mathrm{mol} / \mathrm{mL}$, $\mathrm{P}<0.01)$ decreased significantly compared to the control group but did not differ significantly from those of the sham $(144.45 \pm 6.7 \mu \mathrm{mol} /$ $\mathrm{mL}$ ) and $\mathrm{I} / \mathrm{R}$ groups.

- Table 1 Comparison of creatinine clearance $(\mathrm{CCr})$, absolute $\left(\mathrm{UNaV}^{\circ}\right)$ and relative (FENa) excretions of sodium and absolute $\left(\mathrm{UkV}^{\circ}\right)$ and relative $(\mathrm{FEk})$ excretions of potassium.

\begin{tabular}{|c|c|c|c|c|c|}
\hline $\mathrm{C}_{\mathrm{Cr}} \mu \mathrm{l} / \mathrm{min} . \mathrm{gkw}$ & $\begin{array}{l}\mathrm{U}_{\mathrm{Na}} \mathrm{V}^{0} \mu \mathrm{mol} / \mathrm{min} . \\
\mathrm{gkw}\end{array}$ & $\begin{array}{l}\mathrm{U}_{\mathrm{K}} \mathrm{V}^{0} \mu \mathrm{mol} / \mathrm{min} . \\
\mathrm{gkw}\end{array}$ & $\mathrm{FE}_{\mathrm{Na}} \%$ & $\mathrm{FE}_{\mathrm{K}} \%$ & Parameters Groups \\
\hline $0.05 \pm 0.01$ & $0.56 \pm 0.1$ & $2.68 \pm 0.3$ & $0.39 \pm 0.3$ & $28.6 \pm 9.8$ & Control \\
\hline $0.05 \pm 0.01$ & $0.58 \pm 0.1$ & $2.16 \pm 0.2$ & $0.28 \pm 0.05$ & $42.7 \pm 13.8$ & Sham \\
\hline $\begin{array}{l}0.008 \pm 0.005 \\
* * * \\
+++\end{array}$ & $0.47 \pm 0.1$ & $\begin{array}{l}0.82 \pm 0.2 \\
* * * \\
+++\end{array}$ & $0.42 \pm 0.2$ & $\begin{array}{l}42.7 \pm 13.3 \\
*\end{array}$ & $1 / R$ \\
\hline $\begin{array}{l}0.02 \pm 0.006 \\
* \\
\text { 믐 ㅁ } \\
+\end{array}$ & $0.49 \pm 0.1$ & $\begin{array}{l}1.33 \pm 0.2 \\
* * * \\
+\end{array}$ & $\begin{array}{l}0.001 \pm 0.0008 \\
* \\
\text { ㅁ ㅁ }\end{array}$ & $\begin{array}{l}21.7 \pm 7.7 \\
+ \\
\end{array}$ & $\mathrm{TNG}+\mathrm{I} / \mathrm{R}$ \\
\hline
\end{tabular}

- Table 2 Comparison of urinary concentrations of sodium $\left([\mathrm{Na}]_{u}\right)$, potassium $\left([\mathrm{K}]_{u}\right)$, creatinine $\left([\mathrm{Cr}]_{u}\right)$ and osmolality $\left.(\text { Osmol })_{u}\right)$ among the groups.

\begin{tabular}{|c|c|c|c|c|}
\hline $\mathrm{Osmol}_{\mathrm{u}} \mathrm{mosm} / \mathrm{KgH}_{2} \mathrm{O}$ & {$[\mathrm{Cr}]_{\mathrm{u}} \mathrm{mg} / \mathrm{dl}$} & {$[\mathrm{K}]_{\mathrm{u}} \mu \mathrm{mol} / \mathrm{ml}$} & {$[\mathrm{Na}]_{\mathrm{u}} \mu \mathrm{mol} / \mathrm{ml}$} & Parameters Groups \\
\hline $1515 \pm 70.5$ & $1.38 \pm 0.2$ & $133.63 \pm 13.6$ & $28.72 \pm 8.4$ & Control \\
\hline $1493.83 \pm 80.8$ & $1.33 \pm 0.3$ & $120.28 \pm 9.1$ & $32.33 \pm 3.9$ & Sham \\
\hline $\begin{array}{l}908.33 \pm 48.1 \\
* * * \\
+++\end{array}$ & $1.25 \pm 0.2$ & $\begin{array}{l}112.9 \pm 2.7 \\
* *\end{array}$ & $\begin{array}{l}65.73 \pm 6.9 \\
* * *\end{array}$ & $1 / R$ \\
\hline $\begin{array}{l}1031.5 \pm 58.2 \\
* * * \\
+++\end{array}$ & $1.32 \pm 0.2$ & $\begin{array}{l}88.76 \pm 5.8 \\
* * * \\
+++ \\
\text { ㅁ }\end{array}$ & $\begin{array}{l}32.11 \pm 5.3 \\
\text { 믐 }\end{array}$ & $T N G+1 / R$ \\
\hline
\end{tabular}

$\mathrm{P}<0.001^{* * *}, \mathrm{P}<0.01 * *, \mathrm{P}<0.05^{*}$ compared to the control group. $\mathrm{P}<0.001+++, \mathrm{P}<0.01++, \mathrm{P}<0.05+$ compared to the sham group. $\mathrm{P}<0.001^{\square} \mathrm{\square}, \mathrm{P}<0.01^{\square}, \mathrm{P}<0.05^{\square}$ compared to the I-R group. Results expressed in mean \pm standard deviation (SD) for 6 rats in each group.

- Table 3 Comparison of plasma concentrations of sodium $\left([\mathrm{Na}]_{\mathrm{p}}\right)$, potassium $\left([\mathrm{K}]_{\mathrm{p}}\right)$, creatinine $\left([\mathrm{Cr}]_{\mathrm{p}}\right)$ and osmolality $\left(\right.$ Osmol $\left.\mathrm{p}_{\mathrm{p}}\right)$ among the groups.

\begin{tabular}{|c|c|c|c|c|c|}
\hline $\mathrm{Osmol}_{\mathrm{p}} \mathrm{mosm} / \mathrm{KgH}_{2} \mathrm{O}$ & {$[B U N]_{p} \mathrm{mg} / \mathrm{dl}$} & {$[\mathrm{Cr}]_{\mathrm{p}} \mathrm{mg} / \mathrm{dl}$} & {$[\mathrm{K}]_{\mathrm{p}} \mu \mathrm{mol} / \mathrm{ml}$} & {$[\mathrm{Na}]_{\mathrm{p}} \mu \mathrm{mol} / \mathrm{ml}$} & Parameters Groups \\
\hline $309.16 \pm 30.2$ & $18.76 \pm 2.4$ & $0.55 \pm 0.09$ & $3.66 \pm 0.4$ & $152.1 \pm 6.1$ & Control \\
\hline $305.66 \pm 6.1$ & $24.9 \pm 3.1$ & $0.64 \pm 0.08$ & $3.79 \pm 0.4$ & $144.45 \pm 6.7$ & Sham \\
\hline $318.83 \pm 10.06$ & $\begin{array}{l}41.11 \pm 6.5 \\
* * * \\
++\end{array}$ & $\begin{array}{l}1.24 \pm 0.3 \\
* * * \\
+++\end{array}$ & $4.02 \pm 0.5$ & $149.23 \pm 6.2$ & $I / R$ \\
\hline $332.16 \pm 19.7$ & $\begin{array}{l}38.18 \pm 4.3 \\
* * * \\
+\end{array}$ & $\begin{array}{l}0.77 \pm 0.1 \\
\text { 마 }\end{array}$ & $3.91 \pm 0.5$ & $\begin{array}{l}141.46 \pm 2.6 \\
* * *\end{array}$ & $\mathrm{TNG}+\mathrm{I} / \mathrm{R}$ \\
\hline
\end{tabular}


The plasma concentration of potassium and osmolality did not show any significant differences between groups ( $\triangleright$ Table 3 ).

\section{Post-treatment effects of NG on MDA and FRAP levels in renal tissue}

Results showed that the MDA level per gram kidney weight ( $\mathrm{gkw}$ ) significantly increased in the I-R group $(35.68 \pm 6.41 \mu \mathrm{mol} / \mathrm{gkw})$ compared to the control group $(15.33 \pm 4.21 \mu \mathrm{mol} / \mathrm{gkw})$ and the sham group $(20.41 \pm 3.3 \mu \mathrm{mol} / \mathrm{gkw})(P<0.001)$. The MDA levels did not differ significantly in the sham and control groups. The MDA level in the NG group $(24.66 \pm 2.4 \mu \mathrm{mol} / \mathrm{gkw})$ exhibited a significant increase compared to the control and sham groups $(\mathrm{P}<0.01)$ and $a$ significant reduction compared to the $I-R$ group $(P<0.01$; $>$ Fig. $2 a)$.

In the I-R group the kidney tissue level of FRAP $(5.69 \pm 0.5 \mathrm{mmol} /$ $\mathrm{gkw})$ declined significantly compared to the control group $(8.61 \pm 1.06 \mathrm{mmol} / \mathrm{gkw})$ and the sham group $(7.59 \pm 0.3 \mathrm{mmol} /$ $\mathrm{gkw})$. The tissue level of FRAP were not significantly different in the control and sham groups. The FRAP level in the NG group (8.69 \pm $1.4 \mathrm{mmpl} / \mathrm{gkw}$ ) increased significantly compared to the I-R group $(P<0.001)$, but did not differ significantly from that of the control group ( $\triangleright$ Fig. 2b).

\section{Post-treatment effects of NG on histological changes ( Fig. 3)}

Results demonstrated that necrosis of tubular cells (grade 3 ), vacuolation of tubular cells (grade 2), increased Bowman's capsule space (grade 1), formation of protein casts within the tubular lumen (grade 2 ), scattering of cells into the tubule lumen (grade 3 ), reduction in the number of glomerular red blood cells (grade 1), and glomerular injury (grade 2 ) in the I-R group were significantly different compared to the control group (grade 0) $(P<0.05)$. Increased Bowman's capsule space and cell necrosis in the sham group (grade 1 ) were significantly different compared to the control group $(P<0.05)$. Moreover, necrosis of tubular cells (grade 1 ), vacuolation of tubular cells (grade 0 ), formation of protein casts within the tubular lumen (grade 0 ), scattering of cells inside the tubular lumen (grade 0 ), reduction in the number of glomerular red blood cells (grade 0 ), and glomerular injury (grade 0 ) were significantly different compared to the I-R group $(P<0.05)$, whereas the increase in Bowman's capsule space (grade 1 ) was not significantly different compared to the I-R group ( $\triangleright$ Fig. 3 ).

In the NG group, necrosis of tubular cells (grade 2) significantly increased compared to the control and sham groups $(P<0.05)$, but declined significantly compared to I-R group $(P<0.05)$. In the NG group, increased Bowman's capsule space (grade 2 ), formation of protein casts (grade 2 ), vacuolation (grade 2 ), glomerular injury (grade 2), cell scattering (grade 2 ) and reduction in the number of glomerular red blood cells (grade 1 ) were not significantly different compared to the I-R group ( $\triangleright$ Table 4).

\section{Discussion}

The results of the present study indicated that renal ischemia-reperfusion injury accompanied by increased plasma creatinine and BUN and by reduced creatinine clearance [29]. These results could be due to back-leak of filtrate and impaired ion re-absorption that leads to renal tubular obstruction with the decrease in GFR in the reperfusion stage. Furthermore, sodium is not appropriately re-absorbed by the injured proximal tubules (which activates tubuloglomerular feedback). This feedback probably participates in constriction of pre glomerular arteries that further decreases GFR [30]. The creatinine clearance level in the NG group increased significantly compared to the I-R group. Previous research has shown that NG increases NO and cGMP levels [31]. Increased intracellular cGMP levels dilate the afferent and efferent arteries, thus increasing clearance of creatinine [32]. There was a plasma electrolyte disorder in the I-R group compared to the control group. The $\mathrm{FE}_{\mathrm{Na}}$ in the I-R group increased compared to the control group, but this increase was not significant. The $\mathrm{FE}_{\mathrm{K}}$ was also higher in the I-R group. This increase indicates that epithelial tubular cells, especially proximal tubular cells, are damaged during ischemia-reperfusion injury [26]. In addition, ischemia-reperfusion injury causes brush border destruction with reduced re-absorption of sodium by proximal tubules, impaired expression of tubular sodium transporters, and unsuitable regulation of $\mathrm{Na}^{+} / \mathrm{K}^{+}$-ATPase expression in the basal-lat-

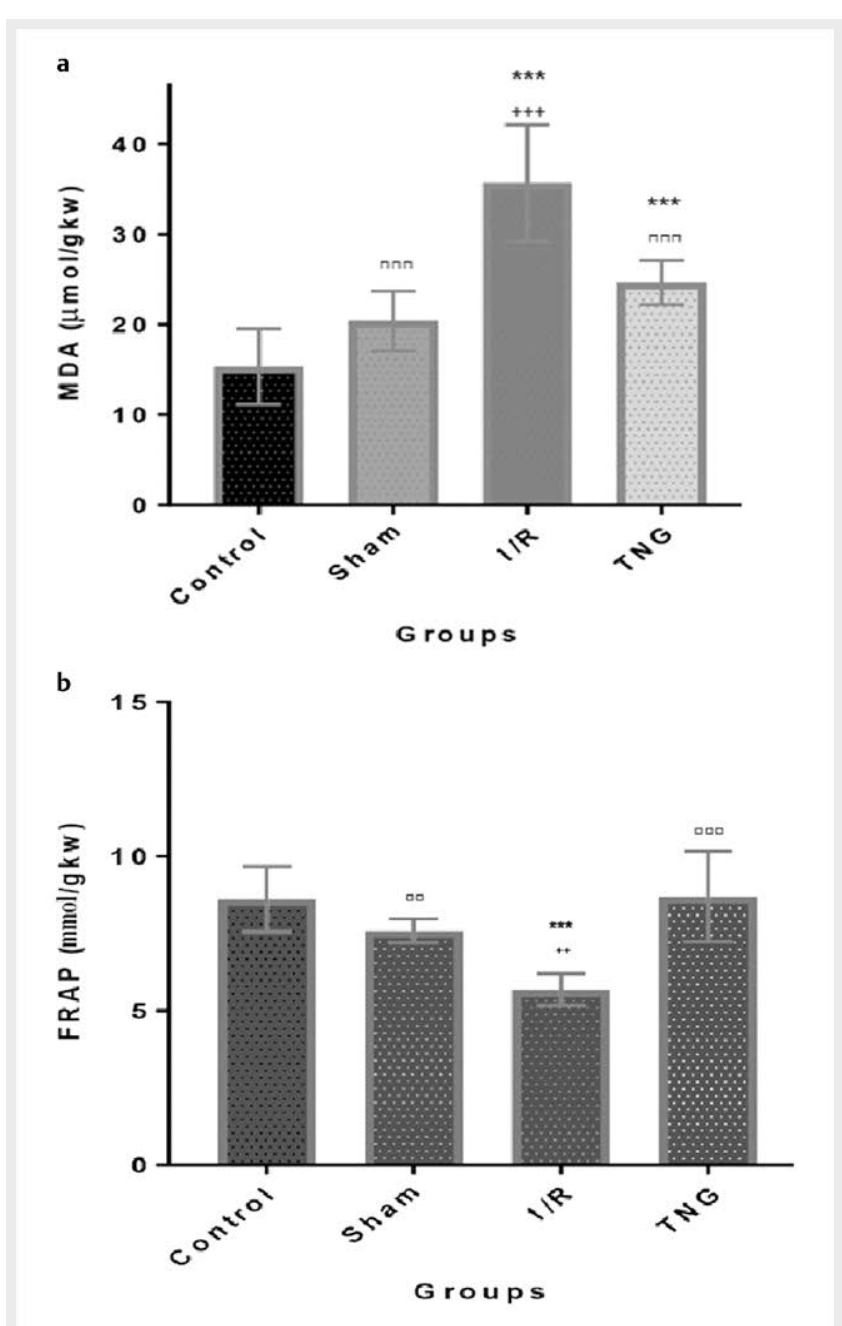

Fig. 2 Comparison of $\mathbf{a}$ MDA and $\mathbf{b}$ FRAP levels among the groups. $\mathrm{P}<0.001 * * *$ compared to the control group, $\mathrm{P}<0.001+++, \mathrm{P}<0.01++$ compared to the sham group, $P<0.001 \square \square \square, P<0.01 \square \square$ compared to the I-R group, Results expressed in mean \pm standard deviation (SD) for 6 rats in each group. 

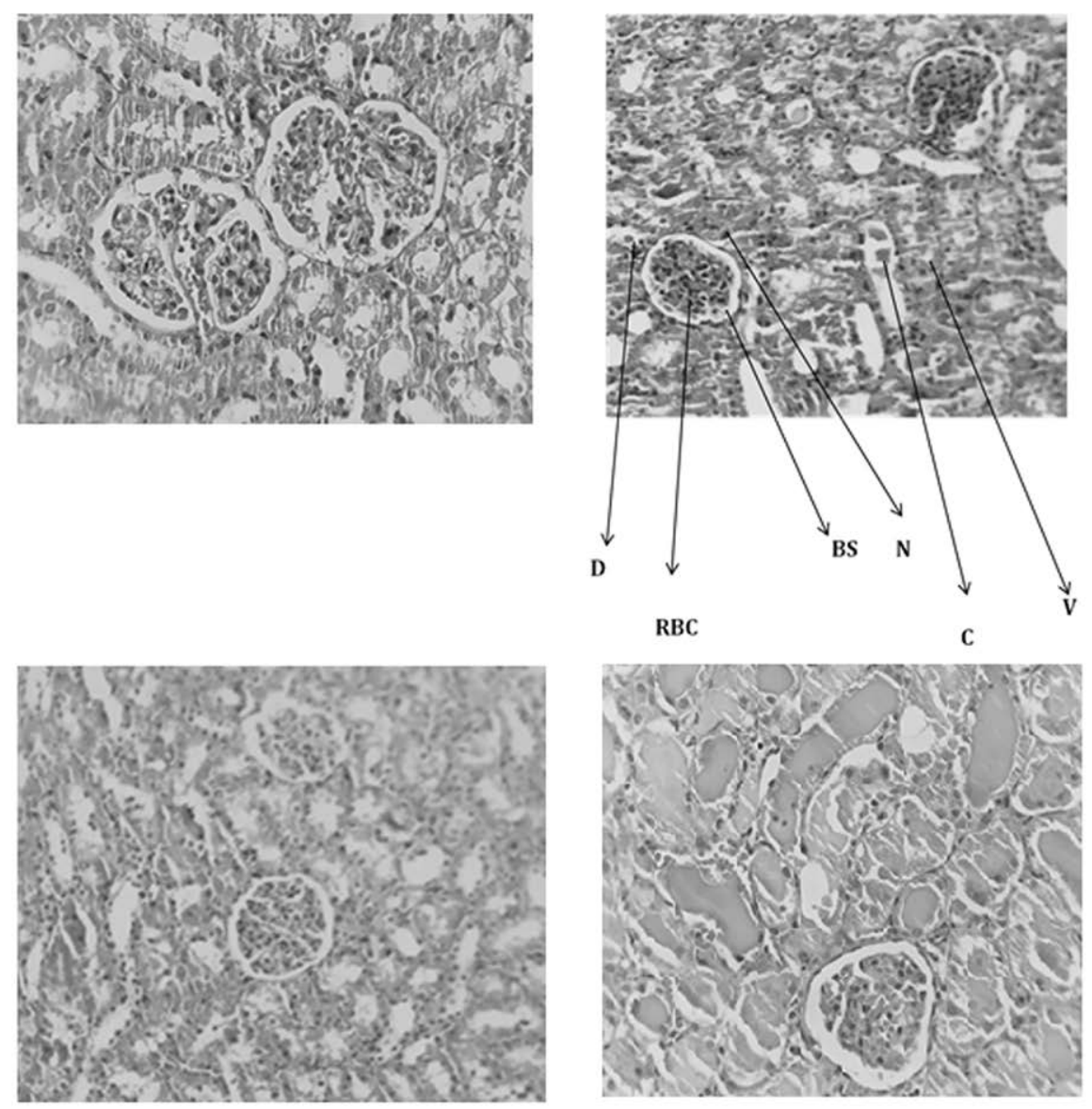

- Fig. 3 Comparison of renal histological between different groups. a - Control group with glomerular and normal tubular structure( $\times 40)$; b- I-R group with tubular cell necrosis, formation of protein casts inside the tubule lumen, cells scattering into the tubule lumen, vacuolation of tubular cells, increased Bowman's space and reduced number of red blood cells in glomerulus $(\times 40)$; $\mathbf{c}$ - sham group with tubular cell necrosis $(\times 40)$; $\mathbf{d}-\mathrm{Ni}$ troglycerin group with increased Bowman's space, vacuolation of tubular cells and reduced tubular cell necrosis $(\times 40)$. RBC: Red Blood Cell, N: Necrosis, C: Intratubular cast, D: Downfall, V: Vacuolization, BS: Bowman's space.

- Table 4 Comparison of necrosis level, protein casts, cell scattering, vacuolation, the reduced number of red blood cells, increased Bowman's capsule space, and glomerular injury.

\begin{tabular}{|c|c|c|c|c|c|c|c|}
\hline Parametes & $\begin{array}{l}\text { Cell } \\
\text { necrosis }\end{array}$ & $\begin{array}{l}\text { Vacuola- } \\
\text { tion }\end{array}$ & $\begin{array}{l}\text { Increased } \\
\text { Bowman's capsular } \\
\text { space }\end{array}$ & $\begin{array}{l}\text { Formation of } \\
\text { protein casts }\end{array}$ & $\begin{array}{l}\text { Cell } \\
\text { scattering }\end{array}$ & $\begin{array}{l}\text { Reduced number } \\
\text { of red blood cells }\end{array}$ & $\begin{array}{l}\text { Glomerular } \\
\text { injury }\end{array}$ \\
\hline \multicolumn{8}{|l|}{ Groups } \\
\hline Control & 0 & 0 & 0 & 0 & 0 & 0 & 0 \\
\hline Sham & $\begin{array}{l}1 \\
* \\
\square \\
\end{array}$ & 0 & $\begin{array}{l}1 \\
*\end{array}$ & 0 & 0 & 0 & 0 \\
\hline$I / R$ & $\begin{array}{l}3 \\
* \\
+ \\
\end{array}$ & $\begin{array}{l}2 \\
* \\
+ \\
\end{array}$ & $\begin{array}{l}1 \\
*\end{array}$ & $\begin{array}{r}2 \\
* \\
+ \\
\end{array}$ & $\begin{array}{l}2 \\
* \\
+ \\
\end{array}$ & $\begin{array}{l}1 \\
* \\
+ \\
\end{array}$ & $\begin{array}{l}2 \\
* \\
+ \\
\end{array}$ \\
\hline$T N G+I / R$ & $\begin{array}{l}2 \\
* \\
+ \\
0\end{array}$ & $\begin{array}{l}2 \\
* \\
+\end{array}$ & $\begin{array}{l}2 \\
* \\
+ \\
+\end{array}$ & $\begin{array}{l}2 \\
* \\
+\end{array}$ & $\begin{array}{l}2 \\
* \\
+\end{array}$ & $\begin{array}{l}1 \\
* \\
+\end{array}$ & $\begin{array}{l}2 \\
* \\
+\end{array}$ \\
\hline
\end{tabular}


eral membranes [23,33]. During I-R, damage to the principal cells of the late portion of the distal tubule and the cortical collecting duct results in direct injury to cells responsible for $\mathrm{K}^{+}$secretion [34]. The NG decreased urinary sodium secretion compared to the I-R group. These results can be due to the fact that the effect of NO on tubular sodium transport differs in the various parts of the nephrons. Results obtained by Wu et al. indicated that during the direct inhibitory effect of $\mathrm{NO}$ on renal proximal tubular $\mathrm{Na}^{+}$transport, the renal sympathetic nervous system stimulated proximal tubular $\mathrm{Na}^{+}$transport during I-R injury. Many studies have been conducted on isolated tubule segments and not on intact kidneys [35]. Moreover, NG increases plasma renin activity [36]. In cortical collecting ducts (CCD), NO inhibits basolateral potassium conductance [37]. Urine osmolality in the I-R group significantly declined compared to the control group due to impaired urinary concentrating ability. Unsuitable regulation of the AQPs and $\mathrm{Na}^{+}$transporter proteins in renal tubules is responsible for changes in sodium and water regulation under the influence of ischemia-reperfusion injury [23]. Urine osmolarity in the NG group was not significantly different from that of the I-R group. This may be due to the effect of NO because it inhibits ADH-sensitive sodium and water permeability in the principle cells through a cGMP increasing mechanism $[37,38]$. Ischemia-reperfusion injury significantly increased the MDA levels and significantly decreased the FRAP levels in the kidney tissues. Previous research demonstrated that ischemia-reperfusion injury caused an imbalance between ROS sources and the antioxidant defense system (reduced glutathione peroxidase, catalase, and superoxide dismutase) [39]. During the reperfusion phase, the produced oxygen free radicals lead to lipid peroxidation [40]. The NG decreased MDA level compared to the I-R group and increased the FRAP level compared to the I-R group. Previous studies indicated that treatment with NG increased plasma catalase and glutathione peroxidase activity while reducing malondialdehyde levels in rats also NG improved antioxidant properties [41]. In the present study, the groups did not significantly differ in blood pressure probably due to the intervention of short-and intermediateterm blood pressure control mechanisms whereas kidneys are longterm blood pressure regulators.

In the present study, Ischemia-reperfusion injury significantly decreased the renal blood flow rates compared to the sham and control groups probably due to the fact that increased renal vascular resistance (RVR) could act as a vascular response to cellular events that happened because of ischemia. Increased RVR may activate vasoactive factors and ROSs that can influence perfusion. Ischemia-reperfusion injury activated the sympathetic nervous system, the renin-angiotensin system and also increased generation of endothelin A, prostaglandins and platelet-activating factors (PAF) among vasoconstrictor agents effective in reducing RBF [42]. The RBF rates in the sham group decreased significantly compared to the control group probably due to effects of anesthesia and surgical stress. Research by Mercatello showed that anesthesia drugs influenced renal function not only directly, but also through changes in cardiovascular function and endocrine activity. Many barbiturates tend to decrease RBF [43]. The RBF rates in the NG group increased significantly compared to the I-R group. Previous studies indicated that NG inhibited contraction of vascular smooth mus- cles through increasing cGMP and reduced effect of exogenous endothelin-1 on heart and kidney function. NG also neutralizes increases in EP, NE, and aldosterone caused by Endothelin [31]. Histological studies in the present research revealed that, contrary to the control group, necrosis of tubular cells, vacuolation of tubular cells, increased Bowman's capsule space, formation of protein casts within the tubular lumen, cell scattering into the tubular lumen, decreased number of glomerular red blood cells, and glomerular injury happened in the I-R group. The pathological analysis did not show the improvement effect in the group that received the drug. Imbalance between expression and activity of eNOS and iNOS (reduction in eNOS activity and increase in iNOS expression level) is responsible for the pathology results during I-R injury [9]. Previous research also did not show any improvement in the histological changes during I-R injury by the NG [44]. The authors believe that the time of using NG also plays a very important role in pathological changes.

\section{Conclusions}

Results of the present study indicated that post-treatment intraperitoneal injection of Nitroglycerin reduces renal ischemia reperfusion injury. Nitroglycerin improved the renal tissue antioxidant defense system by increasing level of FRAP and also reducing lipid peroxidation. Nitroglycerin improved hemodynamic parameters the same as plasma creatinine, creatinine clearance, and renal blood flow through generation of nitric oxide (NO).

Further investigation requires determining the protective effect of nitroglycerin against renal ischemia-reperfusion injury in human kidneys. Additional examinations need to determine the incidence of renal ischemia-reperfusion injury in nitroglycerin-treated patients with acute heart failure.

\section{IRB Ethical Approval Number}

The Research Ethics Committee of Arak University of Medical Sciences approved this research under registration number IR.ARAKMU.REC. 1396.287.

\section{Informed Consent}

This was not a research on humans. All ethical codes developed by the Monitoring Committee for Laboratory Animals at Arak University of Medical Sciences were complied within the experiments conducted in the present research.

\section{Support sources}

Deputy of Education and Research, Arak University of Medical Sciences, Grant number:2858.

\section{Acknowledgement}

Financial support for this research was provided by the Research Deputy of Arak University of Medical Sciences. 


\section{References}

[1] Makris K, Spanou L. Acute kidney injury: Definition, pathophysiology and clinical phenotypes. The Clinical Biochemist Reviews 2016; 37-85

[2] Palevsky PM. Definition and staging criteria of acute kidney injury in adults. 2018 uptodate.com

[3] Patschan D, Müller GA. Acute kidney injury. Journal of Injury and Violence Research 2015; 7-19

[4] Bonventre JV, Yang L. Cellular pathophysiology of ischemic acute kidney injury. The Journal of Clinical Investigation 2011; 121: 4210-4221

[5] Sancho-Martínez SM, López-Novoa JM, López-Hernández F]. Pathophysiological role of different tubular epithelial cell death modes in acute kidney injury. Clinical Kidney Journal 2015; 8: 548-559

[6] Le Clef N, Verhulst A, D'Haese PC et al. Unilateral renal ischemiareperfusion as a robust model for acute to chronic kidney injury in mice. PloS One 2016; 11: e0152153

[7] Tousoulis D, Kampoli AM, Tentolouris Nikolaos et al. The role of nitric oxide on endothelial function. Current Vascular Pharmacology 2012; 10: 4-18

[8] Nath R, Dixit R, Pal R et al. Nitric oxide (NO) a free radical and a messenger molecule.International. Journal of Current Research 2013 5: 907-911

[9] Badavi M, Naseri MKG, Pirmoradi L et al. Beta carotene modulates nitric oxide production in the renal ischemia/reperfusion injury in rat. Zahedan Journal of Research in Medical Sciences 2017; 19 (3): e7662

[10] Roberts BW, Mitchell J, Kilgannon JH et al. Nitric oxide donor agents for the treatment of ischemia/reperfusion injury in human subjects: A Systematic Review. Shock 2013; 39: 229-239

[11] Phillips L, Toledo AH, Lopez-Neblina F et al. Nitric oxide mechanism of protection in ischemia and reperfusion injury. Journal of Investigative Surgery 2009; 22: 46-55

[12] Förstermann U, Sessa WC. Nitric oxide synthases: Regulation and function. European Heart Journal 2011; 33: 829-837

[13] Polakowska M, Orzelska-Gorka J, Talarek S. Drugs modulating the L-arginine: NO: cGMP pathway-current use in therapy. Current Issues in Pharmacy and Medical Sciences 2016; 29: 14-20

[14] Zahoor MU, Masroor R, Ali MW. Use of lignocaine or nitroglycerine for blunting of hemodynamic stress response during electroconvulsive therapy. Egyptian Journal of Anaesthesia 2014; 30: 27-30

[15] Hesketh EE, Czopek A, Clay M et al. Renal ischaemia reperfusion injury: A mouse model of injury and regeneration. Journal of Visualized Experiments 2014; 88: e 51816

[16] Suleyman Z, Sener E, Kurt $N$ et al. The effect of nimesulide on oxidative damage inflicted by ischemia-reperfusion on the rat renal tissue. Renal failure 2015; 37: 323-331

[17] Zou L, Wang W, Liu S et al. Spontaneous hypertension occurs with adipose tissue dysfunction in perilipin-1 null mice. Biochimica et Biophysica Acta (BBA)-Molecular Basis of Disease 2016; 1862 : 182-191

[18] Hajihashemi S, Hamidizad Z, Rahbari A et al. Effects of cobalamin (Vitamin B12) on gentamicin induced nephrotoxicity in rat. Drug research 2017; 67: 710-718

[19] Mukai K, Kuda Y, Shibamoto T et al. Renal response to anaphylaxis in anesthetized rats and isolated perfused rat kidneys: Roles of nitric oxide. The Journal of Physiological Sciences 2018; 68: p 689-697

[20] Hajihashemi S, Jafarian T, Ahmadi M et al. Ameliorative effects of zataria multiflora hydro-alcoholic extract on gentamicin induced nephrotoxic-ity in rats. Drug research 2018; 68: 387-394
[21] Cao Y, Gao X, Yang Y et al. Changing expression profiles of longnoncoding RNAs, mRNAs and circular RNAs in ethylene glycolinduced kidney calculi rats. BMC genomics 2018; 19: 660

[22] Antony AS, Gomathy S, Rajmohan T et al. Pharmacological evaluation of curcumin for its nephroprotective activity in 5/6 nephrectomized rat model. Drug Invention Today 2018; 10: 10-13

[23] Kristensen MLV, Kierulf-Lassen C, Nielsen PM et al. Remote ischemic perconditioning attenuates ischemia/reperfusion-induced downregulation of AQP2 in rat kidney. Physiological reports 2016; 4: e12865

[24] Ahmadi M, Hajihashemi S, Rahbari A et al. The effects of diclofenac on renal toxicity disorders induced by gentamicin in rats. Journal of Babol University of Medical Sciences 2018; 20: 33-41

[25] Chole RH, Patil RN, Basak A et al. Estimation of serum malondialdehyde in oral cancer and precancer and its association with healthy individuals, gender, alcohol, and tobacco abuse. Journal of Cancer Research and Therapeutics 2010; 6: 487-491

[26] Ustundag Y, Huysal K, Kahvecioglu S et al. Establishing reference values and evaluation of an in-house ferric reducing antioxidant power (FRAP) colorimetric assay in microplates. The European Research Journal 2016; 2: 126-131

[27] Ahmadi M, Hajihashemi S, Chehrei A et al. Therapeutic effects of Urtica dioica methanolic extract on gentamicin induced nephrotoxicity in rats. Koomesh 2014; 15: 220-231

[28] Yu C, Qi D, Sun J-F et al. Rhein prevents endotoxin-induced acute kidney injury by inhibiting NF-KB activities. Scientific reports 2015; 5: 11822

[29] Basile DP, Anderson MD, Sutton TA. Pathophysiology of acute kidney injury. Comprehensive Physiology 2011; 2: 1303-1353

[30] Chatauret N, Badet L, Barrou B et al. Ischemia-reperfusion: From cell biology to acute kidney injury. Progrès en urologie 2014; 24: S4-S12

[31] Miller WL, Cavero PG, Aarhus LL et al. Endothelin-mediated cardiorenal hemodynamic and neuroendocrine effects are attenuated by nitroglycerin in vivo. American Journal of Hypertension 1993; 6: 156-163

[32] Krishnan S, Kraehling J, Eitner $F$ et al. The Impact of the nitric oxide (NO)/soluble guanylyl cyclase (sGC) signaling cascade on kidney health and disease: A preclinical perspective. International Journal of Molecular Sciences 2018; 19: 1712

[33] Vallon V. Tubular transport in acute kidney injury: Relevance for diagnosis, prognosis and intervention. Nephron 2016; 134: 160-166

[34] Palmer BF. Potassium homeostasis in chronic kidney disease. Nephrology News \& Issues 2016; 30: suppl 8-10 12-13

[35] Mount P, Power DA. Nitric oxide in the kidney: Functions and regulation of synthesis. Acta Physiologica 2006; 187: 433-446

[36] Chow SL, O'barr SA, Peng J et al. Renal function and neurohormonal changes following intravenous infusions of nitroglycerin versus nesiritide in patients with acute decompensated heart failure. Journal of Cardiac Failure 2011; 17: 181-187

[37] Sharma S. Nitric oxide and the kidney. Indian J Nephrol 2004; 14: $77-84$

[38] Lee J. Nitric oxide in the kidney: its physiological role and pathophysi ological implications. Electrolyte \& Blood Pressure 2008; 6: 27-34

[39] Sabbahy ME, Vaidya VS. Ischemic kidney injury and mechanisms of tissue repair. Wiley Interdisciplinary Reviews: Systems Biology and Medicine 2011; 3: 606-618

[40] Hutchens MP, Dunlap J, Hurn PD et al. Renal ischemia: does sex matter? Anesthesia \& Analgesia 2008; 107: 239-249

[41] Sen S, Doger FK, Sen S et al. The protective effect of nitroglycerin on gastrointestinal and renal side effects of lornoxicam in rats. European Journal of Pharmacology 2006; 541: 191-197 
[42] Basile P, D Yoder MC. Renal endothelial dysfunction in acute kidney ischemia reperfusion injury. Cardiovascular \& Haematological Disorders-Drug Targets (Formerly Current Drug Targets- Cardiovascular \& Hematological Disorders) 2014; 14: 3-14

[43] Mercatello A. Changes in renal function induced by anesthesia. In Annales francaises d'anesthesie et de reanimation. 1990; 9: 507-524
[44] Kucuk HF, Kaptanoglu L, Ozalp F et al. Role of glyceryl trinitrate, a nitric oxide donor, in the renal ischemia-reperfusion injury of rats. European surgical research 2006; 38: 431-437 